Research Article

\title{
Analgesic and anti-inflammatory activity of hydroalcoholic extract of Piper betle leaves in experimental animals
}

\author{
Pooja S. Reddy ${ }^{*}$, Rajesh K. Gupta ${ }^{1}$, Srikanth M. Reddy ${ }^{2}$
}

${ }^{1}$ Department of Pharmacology,

${ }^{2}$ Department of Psychiatry,

Mahatma Gandhi Institute of

Medical Sciences, Sevagram,

Wardha district, Maharashtra-

442102, India

Received: 28 March 2016

Accepted: 27 April 2016

*Correspondence to:

Dr. Pooja S. Reddy,

Email: drpoojasreddy

@ gmail.com

Copyright: (C) the author(s), publisher and licensee Medip Academy. This is an openaccess article distributed under the terms of the Creative Commons Attribution NonCommercial License, which permits unrestricted noncommercial use, distribution, and reproduction in any medium, provided the original work is properly cited.

\begin{abstract}
Background: Piper betle leaf, commonly known as 'paan' has long been known for its various medicinal properties in traditional medicine but certain properties have remained less explored. We tried to assess the analgesic and anti-inflammatory activities of Piper betle leaves.

Methods: Hydroalcoholic extract of Piper betle leaves (HEPBL) was extracted using soxhlet apparatus and its phytochemical analysis was performed. Wistar rats and Albino mice were used for all the experiments. Acute toxicity study was also done according to OECD guideline no.425 and the test doses were decided accordingly. The experimental models of tail-flick method and acetic acid induced writhing were used to study the analgesic activity whereas carrageenan induced paw edema and cotton pellet granuloma models were used for anti-inflammatory action. Statistical analysis was performed using one-way analysis of variance (ANOVA) followed by Dunnett's test.

Results: HEPBL showed significant analgesic activity at the doses of 100 $\mathrm{mg} / \mathrm{kg}$ and $200 \mathrm{mg} / \mathrm{kg}$, and showed significant anti-inflammatory activity at the doses of $50 \mathrm{mg} / \mathrm{kg}, 100 \mathrm{mg} / \mathrm{kg}$ and $200 \mathrm{mg} / \mathrm{kg}$. The sub-therapeutic dose of HEPBL at $50 \mathrm{mg} / \mathrm{kg}$ also potentiated the analgesic effect of sub-therapeutic doses of standard analgesics. The analgesic and anti-inflammatory activity of P.betle may be attributed to the presence of various phyto constituents' viz. flavonoids, tannins, phenols and glycosides.
\end{abstract}

Conclusions: HEPBL has significant analgesic and anti-inflammatory activity in experimental animals in our study.

Keywords: Piper betle leaf, Sub-therapeutic potential, Analgesic, Antiinflammatory

\section{INTRODUCTION}

Piper betle L., popularly known as 'paan,' has been a part of Indian culture since eternity. Piper betle L. belongs to the Piperaceae family and it grows as a slender, aromatic creeper in warm and moist parts of Southern Asia. ${ }^{1}$ Apart from being an integral part of the history, religion and culture, ancient medical philosophers have always insisted on the medicinal uses of this commonly used rasayana herb. These medicinal properties have mostly remained unexplored by the modern sciences.
The literature has evidence of various beneficial uses of Piper betle $L$. such as treating bronchitis, difficulty in breathing and cough, inflammation and infections of the respiratory tract viz. cough, dyspnoea, indigestion, diphtheria, and hysteria, general and sexual debility. ${ }^{2}$

From the perusal of literature it appears that the analgesic and anti-inflammatory activities of Piper betle leaves have been less explored and hence was found to be of interest to evaluate these activities of Piper betle leaf extract in experimental models. 


\section{METHODS}

Ethical clearance was taken from the institutional animal ethics committee and institutional research committee before commencing the study (Ref. no. MGIMS/IEC/9/2009).

\section{Collection of plant material}

The P.betle leaves were collected from the local market of Wardha, Maharashtra, India and authenticated by an authorized person in botany. The leaves were shadedried, powdered and stored in an air tight container.

\section{Preparation of extract}

The powder was extracted with $70 \%$ ethanol and $30 \%$ distilled water (i.e. hydroalcoholic extract) using soxhlet apparatus at $50-55^{\circ} \mathrm{C}$ for three days. After extraction, the extract was concentrated in an electronic hot water bath. Fifty grams of powder yielded $14 \mathrm{gm}$ of extract after drying and concentrating. The extract was freshly prepared each time by dissolving it in $2 \%$ gum acacia before administering it to the experimental animals.

\section{Phytochemical analysis}

Freshly prepared hydroalcoholic extract of Piper betle leaves (HEPBL) was subjected to phytochemical screening by using standard procedures for detection of various phytoconstituents such as alkaloids, carbohydrates, phenols, flavonoids, steroids, saponins, tannins and glycosides.

\section{Test animals}

Wistar rats weighing $150-220$ gms (8 to 12 weeks old) and swiss albino mice weighing 22-25 g of either sex were used for the study. The animals were procured and housed in the animal house of Mahatma Gandhi institute of medical sciences, Sewagram at least 2 weeks prior to the study for acclimatization. Animal house was well maintained under standard hygienic conditions, at $22 \pm 2$ ${ }^{\circ} \mathrm{C}$, humidity $(60 \pm 10 \%)$ with 12 hours day and night cycle, with food and water ad libitum.

\section{Toxicity study}

Toxicity study for HEPBL was carried out as per OECD guideline number 425 . Healthy young adult albino wistar rats (200-250 g) were used for toxicity study. Animals were fasted overnight prior to dosing. The body weight of each animal was determined to calculate the dose. HEPBL was administered in the dose of $2000 \mathrm{mg} / \mathrm{kg}$ body weight orally to one animal which survived. Thereafter, four other animals were dosed sequentially. All the animals were closely observed for 14 days. As no fatality was observed, $\mathrm{LD}_{50}$ was estimated to be greater than $2000 \mathrm{mg} / \mathrm{kg}^{5}$. After performing a pilot study, it was decided to use $50 \mathrm{mg} / \mathrm{kg}, 100 \mathrm{mg} / \mathrm{kg}$ and $200 \mathrm{mg} / \mathrm{kg}$ of HEPBL for all the experiments.

\section{Drugs}

Aspirin, diclofenac and buprenorphine were purchased from the institutional pharmacy. All other chemicals and reagents used were of analytical grade.

\section{Assessment of analgesic activity}

\section{The analgesic activity of HEPBL was studied by}

- Tail-flick technique in rats

- Acetic acid induced writhing in mice

\section{Administration of drugs}

Animals were randomly divided into 7 groups for both the experimental models with six animals in each group. Group I served as control and was given only $2 \%$ gum acacia (10 ml/kg p.o.). Group II was standard reference group and was administered a standard drug. Group III, IV and $\mathrm{V}$ received HEPBL in the doses of 50, 100 and $200 \mathrm{mg} / \mathrm{kg}$, p.o. respectively. The sub-therapeutic dose of the standard drug was administered in group VI whereas group VII received combination of sub-therapeutic dose of the standard drug and sub-analgesic dose of HEPBL to study the potentiating effect, if any.

- $\quad$ Tail flick technique ${ }^{6}$

The animals were pre-screened and those which showed flicking response within 3-5 sec of exposure to heat stress were selected. A cut off latency period was $15 \mathrm{sec}$ to avoid damage to the tail. The current passing through the naked nicrome wire was maintained at 5 ampere. The tail withdrawal time was assessed at 30, 60 and 120 minutes after administration of drugs. Buprenorphine in the dose of $3 \mathrm{mg} / \mathrm{kg}$, i.p. was used as the standard reference drug administered to the animals in group II. $^{3}$

Pain inhibition percentage $(\mathrm{PIP})=(\mathrm{T} 1-\mathrm{T} 0 / \mathrm{T} 0) \times 100$ (T1: Post drug latency; T0: Pre drug latency)

In addition, the potentiation of analgesic effect of buprenorphine with HEPBL was assessed. The buprenorphine when administered to the group VI in the dose of $1 \mathrm{mg} / \mathrm{kg}$, i.p. showed no significant analgesic response, thereby suggesting that the said dose was subtherapeutic. Group VII received a combination of this sub-therapeutic dose of buprenorphine ( $1 \mathrm{mg} / \mathrm{kg}$, i.p.) and low dose of HEPBL $(50 \mathrm{mg} / \mathrm{kg})$ to study their potentiation effect, if any.

- Acetic acid induced writhing $\operatorname{method}^{8}$

The mice showing a positive writhing response within the period of 20 minutes on administration of $7 \%$ acetic acid $(0.1 / 10 \mathrm{gm})$ intra-peritoneal (i.p.) were included in the 
study. Every mouse was counted for the number of writhing's it made in 30 minutes duration commencing 5 minutes after the intra-peritoneal administration of acetic acid solution. Aspirin (50 mg/kg, p.o.) was used as standard drug (for administration to group II animals). The percentage protection was calculated accordingly.

In addition, group VI received sub-therapeutic dose of aspirin (25 mg/kg, p.o.) whereas group VII received subanalgesic dose of HEPBL (50 $\mathrm{mg} / \mathrm{kg}$, p.o.) in combination with the sub-therapeutic dose of aspirin to study the potentiating action, if any.

\section{Assessment of anti-inflammatory activity}

Anti-inflammatory activity of HEPBL was studied by the following models.

- Carrageenan induced paw edema model

- Cotton pellet induced granuloma model

\section{Administration of drugs}

Animals were randomly divided into 5 groups of six animals each. Group I served as control and was given only $2 \%$ gum acacia $(10 \mathrm{ml} / \mathrm{kg}$, p.o.). Group II was standard reference group of rats administered with standard drug. Group III, IV and V received HEPBL in the doses of 50,100 and $200 \mathrm{mg} / \mathrm{kg}$, p.o. respectively.

- $\quad$ Carrageenan induced paw edema model ${ }^{9}$
Acute inflammation was induced by sub-plantar injection of carrageenan $(0.1 \mathrm{ml}$ of $1 \%$ suspension in normal saline) in the right hind paw of the rats, one hour after oral administration of the drugs. The paw volume was measured plethysmometrically hourly for 3 hours after the carrageenan injection. The difference between the two readings was taken as the volume of edema and the percentage of anti-inflammatory activity was calculated. Aspirin (50 mg/kg, p.o.) was used as standard drug control in group II.

- Cotton pellet granuloma model ${ }^{10}$

Sterile cotton $(10 \pm 1 \mathrm{mg})$ soaked in $0.2 \mathrm{ml}$ of distilled water containing penicillin $(0.1 \mathrm{mg})$ was implanted subcutaneously in axilla under ether anaesthesia. HEPBL, diclofenac sodium $(5 \mathrm{mg} / \mathrm{kg}$, p.o.) and control vehicle ( $2 \%$ gum acacia) were administered daily for 10 days to the respective groups. On the $10^{\text {th }}$ day the pellets were dissected out, dried at $60{ }^{\circ} \mathrm{C}$ and the dry weight was determined to calculate the actual weight of the granuloma.

\section{Statistical analysis}

The descriptive data is presented as mean \pm SEM. The data was analysed by one-way analysis of variance (ANOVA) followed by Dunnett's test. P-value $<0.05$ was considered to be significant.

\section{RESULTS}

Table 1: Effect of treatment with HEPBL on mean reaction latency time by tail flick method in wistar rats.

\begin{tabular}{|c|c|c|c|c|c|c|}
\hline \multirow{3}{*}{$\begin{array}{l}\text { Group } \\
(n=6)\end{array}$} & \multirow{3}{*}{ Treatment } & \multirow{3}{*}{ Dose } & \multirow{3}{*}{$\begin{array}{l}\text { Before } \\
\text { drug } \\
\text { administration }\end{array}$} & \multicolumn{3}{|c|}{ Reaction time in seconds mean \pm SEM (PIP) } \\
\hline & & & & \multicolumn{3}{|c|}{ Time after drug administration } \\
\hline & & & & 30 minutes & 60 minutes & 120 minutes \\
\hline I & Control (2\% gum Acacia) & $10 \mathrm{ml} / \mathrm{kg}$ & $3.41 \pm 0.08$ & $3.02 \pm 0.08$ & $3.12 \pm 0.08$ & $3.64 \pm 0.04$ \\
\hline II & $\begin{array}{l}\text { Buprenorphine (Standard } \\
\text { drug) }\end{array}$ & $3 \mathrm{mg} / \mathrm{kg}$ & $3.65 \pm 0.05$ & $\begin{array}{l}9.07 \pm 0.04 * * \\
(148.4 \%)\end{array}$ & $\begin{array}{l}9.12 \pm 0.02 * * \\
(149.86 \%)\end{array}$ & $\begin{array}{l}9.17 \pm 0.02 * * \\
(151.23 \%)\end{array}$ \\
\hline III & HEPBL (50mg/kg) & $50 \mathrm{mg} / \mathrm{kg}$ & $3.51 \pm 0.14$ & $\begin{array}{l}4.09 \pm 0.20 \\
(16.52 \%)\end{array}$ & $\begin{array}{l}4.25 \pm 0.28 \\
(21.08 \%)\end{array}$ & $\begin{array}{l}4.08 \pm 0.18 \\
(16.23 \%)\end{array}$ \\
\hline IV & HEPBL (100mg/kg) & $100 \mathrm{mg} / \mathrm{kg}$ & $3.85 \pm 0.04$ & $\begin{array}{l}6.41 \pm 0.05^{*} \\
(66.49 \%)\end{array}$ & $\begin{array}{l}6.47 \pm 0.05^{*} \\
(68.05 \%)\end{array}$ & $\begin{array}{l}7.23 \pm 0.05^{*} \\
(87.79 \%)\end{array}$ \\
\hline $\mathrm{V}$ & HEPBL (200mg/kg) & $200 \mathrm{mg} / \mathrm{kg}$ & $3.83 \pm 0.05$ & $\begin{array}{l}7.63 \pm 0.04 * * \\
(91.37 \%)\end{array}$ & $\begin{array}{l}7.85 \pm 0.02 * * \\
(92.15 \%)\end{array}$ & $\begin{array}{l}8.21 \pm 0.03 * * \\
(94.21 \%)\end{array}$ \\
\hline VI & Buprenorphine & $1 \mathrm{mg} / \mathrm{kg}$ & $3.80 \pm 0.03$ & $\begin{array}{l}4.80 \pm 0.08 \\
(26.31 \%)\end{array}$ & $\begin{array}{l}4.91 \pm 0.12 \\
(29.21 \%)\end{array}$ & $\begin{array}{l}4.95 \pm 0.14 \\
(30.26 \%)\end{array}$ \\
\hline VII & Buprenorphine+HEPBL & $\begin{array}{l}1 \mathrm{mg} / \mathrm{kg}+50 \\
\mathrm{mg} / \mathrm{kg}\end{array}$ & $\begin{array}{l}8.07 \pm 0.06 * * \\
(111.81 \%)\end{array}$ & $\begin{array}{l}8.22 \pm 0.02 * * \\
(115.74 \%)\end{array}$ & $\begin{array}{l}8.37 \pm 0.02 * * \\
(119.68 \%)\end{array}$ & $\begin{array}{l}8.07 \pm 0.06 * * \\
(111.81 \%)\end{array}$ \\
\hline
\end{tabular}

Values are expressed as Mean \pm SEM. Analysis was done by one way ANOVA followed by Dunnett's test. *P $<0.01$ and $* * \mathrm{P}<0.001$ as compared to control. HEPBL: Hydroalcoholic extract of Piper betle leaves, PIP: Pain inhibition percentage (\%). Numbers in parenthesis indicate percentage increase in reaction time. 


\section{Phytochemical screening and toxicity study}

The phytochemical screening of HEPBL revealed the presence of flavonoids, phenols, glycosides and tannins. Acute toxicity study revealed that the administration of HEPBL up to a dose of $2000 \mathrm{mg} / \mathrm{kg}$ did not produce any significant change in the behaviour of the animals, the rats were physically active and no death was observed. The study indicated that the median lethal dose $\left(\mathrm{LD}_{50}\right)$ of HEPBL is greater than $2000 \mathrm{mg} / \mathrm{kg}$ body weight.

\section{Analgesic activity assessed by Tail Flick technique}

Hydro alcoholic extract of Piper betle leaves (HEPBL) in the doses of 100 and $200 \mathrm{mg} / \mathrm{kg}$ p.o exhibited significant analgesic activity in a dose dependent manner as evidenced by significant increase in the latency of the reaction time $(\mathrm{P}<0.01$ and $\mathrm{P}<0.001$ respectively) in comparison to the control group of animals. The intraperitoneal administration of buprenorphine in the dose of $3 \mathrm{mg} / \mathrm{kg}$ produced the analgesic activity which was highly significant $(\mathrm{P}<0.001)$. Although Piper betle extract in its low dose i.e. $50 \mathrm{mg} / \mathrm{kg}$, p.o. did not increase the latency time in tail flick technique, it potentiated the analgesic activity of sub-analgesic dose ( $1 \mathrm{mg} / \mathrm{kg}$, i.p.) of buprenorphine. At 120 minutes, pain inhibition percent (PIP) of the combination of low dose of $P$. betle
(50 mg/kg, p.o.) with sub-therapeutic dose of buprenorphine (1 $\mathrm{mg} / \mathrm{kg}$, i.p.) was $119.68 \%$ ( $\mathrm{P}<0.001$ compared to the control) which is comparable to the PIP of the standard therapeutic dose of buprenorphine (3 $\mathrm{mg} / \mathrm{kg}$, i.p.) i.e. $151.23 \%(\mathrm{P}<0.001$ compared to the control) (Table1).

\section{Analgesic activity assessed by acetic acid induced writhing test}

Oral administration of HEPBL in the graded doses (50, 100 and $200 \mathrm{mg} / \mathrm{kg}$, p.o.) suppressed the acetic acid induced writhing response significantly in a dosedependent manner. The percent protection of HEPBL was $45.2 \% \quad(\mathrm{P}<0.05), 76.1 \% \quad(\mathrm{P}<0.01)$ and $79.3 \% \quad(\mathrm{P}<0.01)$ respectively in comparison with control. The standard drug, aspirin, in the dose $50 \mathrm{mg} / \mathrm{kg}$, p.o. produced maximum inhibition of writhing in a 30 min observation time which was $84.8 \%(\mathrm{P}<0.001)$.

Though HEPBL in its low dose i.e. $50 \mathrm{mg} / \mathrm{kg}$, p.o. and aspirin in its sub-therapeutic dose of $25 \mathrm{mg} / \mathrm{kg}$, p.o. exhibited some protection against acetic acid induced writhing, their combination exhibited $83.2 \%$ protection, which was highly significant $(\mathrm{P}<0.001)$ in comparison to the control and was also comparable to the standard dose of Aspirin i.e. $50 \mathrm{mg} / \mathrm{kg}$, p.o. (Table 2).

Table 2: Effect of treatment with HEPBL on acetic acid induced abdominal constriction in mice.

\begin{tabular}{|c|c|c|c|c|}
\hline Group $(n=6)$ & Drug & Dose & Number of writhing's & $\%$ Protection \\
\hline I & Control (2\%gum acacia) & $10 \mathrm{ml} / \mathrm{kg}$ & $66.83 \pm 0.9$ & - \\
\hline II & Aspirin (standard) & $50 \mathrm{mg} / \mathrm{kg}$ & $10.50 \pm 0.5$ & $84.8 \% * * *$ \\
\hline III & HEPBL & $50 \mathrm{mg} / \mathrm{kg}$ & $55.22 \pm 1.3$ & $45.2 \% *$ \\
\hline IV & HEPBL & $100 \mathrm{mg} / \mathrm{kg}$ & $24.00 \pm 1.6$ & $76.1 \% * *$ \\
\hline V & HEPBL & $200 \mathrm{mg} / \mathrm{kg}$ & $14.33 \pm 1.3$ & $79.3 \% * *$ \\
\hline VI & Aspirin & $25 \mathrm{mg} / \mathrm{kg}$ & $43 \pm 1.7$ & $58.4 \% *$ \\
\hline VII & Aspirin+HEPBL & $25 \mathrm{mg} / \mathrm{kg}+50 \mathrm{mg} / \mathrm{kg}$ & $12.33 \pm 0.7$ & $83.2 \% * * *$ \\
\hline
\end{tabular}

Values are expressed as mean \pm SEM. Analysis was done by One way ANOVA followed by Dunnett's test. ${ }^{*} \mathrm{P}<0.05,{ }^{*} \mathrm{P}<0.01$ and ***P <0.001 as compared to control. HEPBL: Hydroalcoholic extract of Piper betle leaves.

Table 3: Effects of HEPBL on carrageenan-induced hind paw edema.

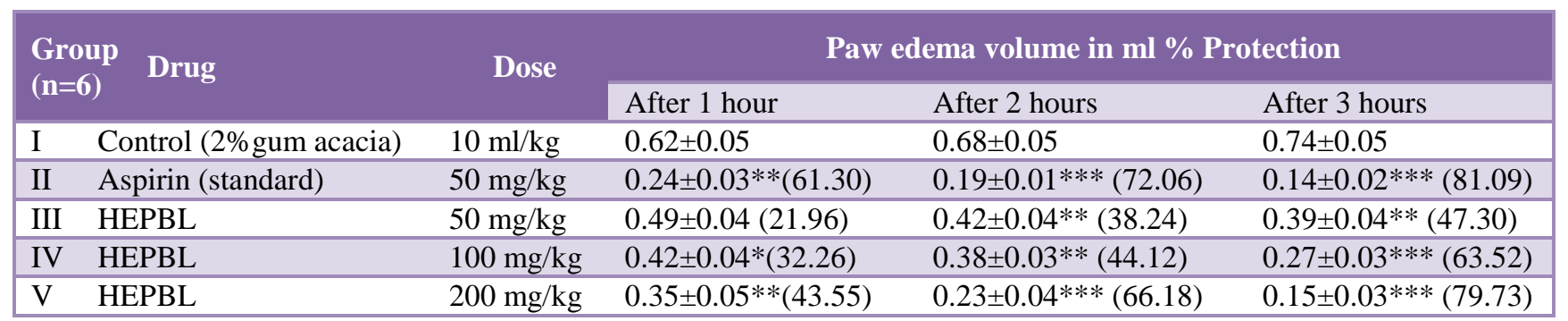

Values are expressed as mean \pm SEM. One way ANOVA followed by Dunnett's test. $* \mathrm{P}<0.05$, **P $<0.01$, *** $\mathrm{P}<0.001$ as compared to control. Values in parentheses indicate percent protection. HEPBL: hydroalcoholic extract of Piper betle leaves. 
Table 4: Effect of treatment with HEPBL on cotton pellet granuloma.

\begin{tabular}{|c|c|c|c|}
\hline $\begin{array}{l}\text { Group } \\
(\mathrm{n}=6)\end{array}$ & Dose & Weight of dry cotton pellet granuloma (mg) & $\%$ Protection \\
\hline Control (2\%gum acacia) & $10 \mathrm{ml} / \mathrm{kg}$ & $77.24 \pm 4.82$ & --- \\
\hline II Diclofenac sodium & $5 \mathrm{mg} / \mathrm{kg}$ & $30.05 \pm 2.66^{* *}$ & $61.09 \pm 2.1 * *$ \\
\hline III HEPBL & $50 \mathrm{mg} / \mathrm{kg}$ & $54.08 \pm 4.13 *$ & $29.97 \pm 1.5^{*}$ \\
\hline IV HEPBL & $100 \mathrm{mg} / \mathrm{kg}$ & $38.04 \pm 1.99 * *$ & $50.76 \pm 1.7 * *$ \\
\hline V HEPBL & $200 \mathrm{mg} / \mathrm{kg}$ & $32.84 \pm 3.12 * *$ & $57.49 \pm 1.9 * *$ \\
\hline
\end{tabular}

Values are expressed as Mean \pm SEM. Values in parentheses indicate percent protection. One way ANOVA followed by Dunnett's test and. $* \mathrm{P}<0.05, * * \mathrm{P}<0.01, * * * \mathrm{P}<0.001$ as compared to control. HEPBL: hydroalcoholic extract of Piper betle leaves.

\section{Anti-inflammatory activity of HEPBL assessed by carrageenan induced hind paw edema model}

In carrageenan induced hind paw edema method, the oral administration of HEPBL in graded doses $(50,100$ and $200 \mathrm{mg} / \mathrm{kg}$ ) produced significant reduction in the paw volume in a dose dependent manner in comparison to the control group of animals. The maximum effect was seen in the dose of $200 \mathrm{mg} / \mathrm{kg}$ orally which showed significant $(\mathrm{P}<0.001)$ reduction in paw volume in comparison to control $(79.73 \%)$. The anti-inflammatory activity of HEPBL in the dose of $200 \mathrm{mg} / \mathrm{kg}$ was comparable to aspirin $(50 \mathrm{mg} / \mathrm{kg}$, p.o.). All the groups showed maximum anti-inflammatory activity after 3 hours' time (Table 3 ).

\section{Anti-inflammatory activity of HEPBL assessed by cotton pellet granuloma model}

In this experimental model HEPBL in graded doses (50, 100 and $200 \mathrm{mg} / \mathrm{kg}$, p.o. for 10 days) showed significant reduction in the dry weights of granuloma in dose dependent manner. Compared to control, $200 \mathrm{mg} / \mathrm{kg}$ dose of HEPBL showed maximum effect with $57.49 \%$ protection $(\mathrm{P}<0.01)$. The anti-inflammatory activity in this dose was also comparable with diclofenac sodium (5 $\mathrm{mg} / \mathrm{kg}$, p.o. for 10 days) which exhibited $61.09 \%$ protection ( $\mathrm{P}<0.01$ compared to control group) (Table 4$)$.

\section{DISCUSSION}

HEPBL (100 mg/kg and $200 \mathrm{mg} / \mathrm{kg}$ ) showed significant analgesia in both the experimental models, tail flick model for centrally acting analgesic effect and acetic acid induced writhing model for peripheral analgesia. P.betles' analgesic potential has been reported in the literature in past as well. Analgesic effect of P.betle extract was also demonstrated by Arambewala et al. ${ }^{11}$ He had used the hot water extract $(125,200,300,500 \mathrm{mg} / \mathrm{kg})$ as well as the cold ethanol extract $(125,200,300,500 \mathrm{mg} / \mathrm{kg}$ ) of P.betle and found that both had significant analgesic activity, the former having more potential to do so. Soumita De et al. attempted exploring the analgesic effect of ethanolic extract of P.betle at the doses of $(25,50$ and 100 $\mathrm{mg} / \mathrm{kg}$ ). ${ }^{12}$ Both 50 and $100 \mathrm{mg} / \mathrm{kg}$ of ethanolic extract of $P$. betle showed significant analgesic activity. The independent analgesic activity was demonstrated at 100 $\mathrm{mg} / \mathrm{kg}$ and $200 \mathrm{mg} / \mathrm{kg}$ in our study but not at $50 \mathrm{mg} / \mathrm{kg}$. Interestingly the sub-threshold dose of HEPBL (50 $\mathrm{mg} / \mathrm{kg}$ ) potentiated the analgesic activity of sub-threshold doses of buprenorphine $(1 \mathrm{mg} / \mathrm{kg})$ and aspirin $(25 \mathrm{mg} / \mathrm{kg})$ in both the experimental models respectively which to the best of our knowledge is the first report indicating potentiation of analgesic action of aspirin and buprenorphine by P.betle leaves.

Theoretically, NSAIDs inhibit the pain peripherally whereas narcotic analgesics inhibit the pain both centrally as well as peripherally. ${ }^{13,14}$ In our study HEPBL showed to inhibit the pain by both the central as well as peripheral mechanism. Hence we assume that the analgesic action of HEPBL could have been mediated through narcotic mechanism. Further if these finding get replicated in human studies, then the HEPBL may serve as a potential augmenting agent for buprenorphine and aspirin, thereby reducing their dose related untoward side-effects.

HEPBL was also shown to possess significant antiinflammatory activity in our study in a dose dependent manner $(50,100,200 \mathrm{mg} / \mathrm{kg})$. This activity of HEPBL was demonstrated using both the acute as well as the subacute inflammatory experimental models. The antiinflammatory effect of HEPBL at a dose of 50, 100 and $200 \mathrm{mg} / \mathrm{kg}$ were statistically significant and also dose dependent. Similar to our study, Ganguly et al. ${ }^{15}$ also tried to explore the anti-inflammatory effects of an ethanolic extract of the leaves of $P$. betle $(100 \mathrm{mg} / \mathrm{kg})$. Instead of the cotton pellet induced granuloma model used in our study, the author demonstrated the anti-inflammatory effect using the complete Freund's adjuvant-induced model of arthritis in rats and compared it with dexamethasone $(0.1 \mathrm{mg} / \mathrm{kg})$ as the positive control. Vaghasiya et al used the crude leaf powder suspesion of 8 Piper species, Piper longum, Piper betle, Piper attanuatum ( Buch-Ham Type 1\& 2), Piper Chaba, Piper Hymenophyllum, Piper Sarmentosu and Piper argyrophyllum to assess their anti-inflammatory effect using carrageenan and dextran models for acute inflammation and cotton pellet induced granuloma for chronic inflammation. He found that Piper betle had significant anti-inflammatory activity in the cotton pellet induced granuloma model there by suggesting the 
inhibition of proliferative phase of the inflammation process.

In the acute inflammatory experimental model used in our study, the probable mechanism of action of carrageenaninduced oedema is bi-phasic, the first phase being attributed to the release of histamine, 5-HT and kinins in the first hour, while the second phase is related to the release of prostaglandin like substances in 2-3 hours. ${ }^{17-19}$ It can be supposed that the HEPBL probably interacts with all these inflammatory mediators responsible for the acute as well as the sub-acute inflammation. In the cotton pellet induced granuloma model, infiltration of macrophages, neutrophils and proliferation of fibroblasts lead to sub-acute inflammation. Any agent showing antiinflammatory response on chronic inflammation has an ability to inhibit the increase in number of fibroblasts during granular tissue formation. ${ }^{20}$ HEPBL demonstrated a decrease in the weight of the granuloma and thereby demonstrating its anti-proliferative effect in chronic inflammation. Preliminary qualitative phytochemical study revealed the presence of flavonoids, phenols, glycosides and tannins in HEPBL. The flavonoids have been reported to inhibit the prostaglandins which are known to mediate the late phase of inflammation and pain. The flavonoids, phenols, glycosides and tannins are known to act beneficially in certain biological phenomena such as wound healing, pain and inflammation. ${ }^{21}$ The individual or combined synergic effects of the various phytoconstituents of HEPBL could possibly be responsible for the analgesic and anti-inflammatory properties of P.betle.

HEPBL showed significant analgesic and antiinflammatory activities comparable to various standard drugs in the preclinical settings. Considering these findings it stands as a useful moiety for use in human population and can be a potential area for future research.

Funding: No funding sources

Conflict of interest: None declared

Ethical approval: The study was approved by the Institutional Ethics Committee

\section{REFERENCES}

1. Arambewela LS, Arambewela LD, Ratanasooriya WD. Antidiabetic activities of aqueous and ethanolic extracts of Piper betle leaves in rats. J Ethnopharmacol. 2005;102:239-45.

2. Bhattacharya S, Chaudhuri SR, Chattopadhyay S, Bandyopadhyay SK. Healing properties of some indian medicinal plants against indomethacininduced gastric ulceration of rats. J Clin Biochem Nutr. 2007;41:106-14.

3. Khandelwal KR. Practical pharmacognosy techniques and experiments. $14^{\text {th }}$ ed. Pune: Nirali Prakashan; 2005:150-3.

4. Hossain MA, AL-Raqmi KAS, AL-Mijizy ZH, Weli AM, Al-Riyami Q. Study of total phenol, flavonoids contents and phytochemical screening of various leaves crude extracts of locally grown Thymus vulgaris. Asian Pac J Trop Biomed. 2013;3:705-10.

5. OECD guidelines for the testing of chemicals test No.425: Acute oral toxicity: Up-and-down procedures. Available at http://www.oecdilibrary.org/environment/test-no-425-acute-oraltoxicity-up-and-down-procedure_9789264071049en;jsessionid=3bahm6w8a9hdk.x-oecd-live-02. Accessed 26 March 2016.

6. Kamath JV, Rana AC. Pharmacological activities of ethanolic extract of Calotropis procera roots. Indian Drugs. 2003;40:292-5.

7. Bruchas MR, Yang T, Schreiber S, Defino M, Kwan SC, Li S, et al. Long-acting kappa opioid antagonists disrupt receptor signaling and produce noncompetitive effects by activating c-Jun Nterminal kinase. J Biol Chem. 2007;282:29803-11.

8. Collier HOJ, Dineen LC, Johnson CA, Schneirder C. Nociceptive response to prostaglandins and analgesic actions of aspirin and morphine. Br $\mathrm{J}$ Pharmacol. 1968;32:295-310.

9. Saha A, Ahmed M. The analgesic and antiinflammatory activities of the extract of Albizia lebbeck in animal model. Pak J Pharm Sci. 2009;22:74-7.

10. Winter CA, Porte CC. Effect of alteration in side chain upon anti-inflammatory and liver glycogen activity of hydrocortisone esters. J Am Pharm Ass Sci. 1957;46:515-9.

11. Arambewela LSR, Arawwawala LDAM, Ratnasooriya WD. Antinociceptive activities of aqueous and ethanol extracts of Piper betle leaves in rats. Pharmaceutical Biology. 2005;43:766-72.

12. De S, Maroo N, Saha P, Hazra S, Chatterjee M. Ethanolic extract of Piper betle Linn. Leaves reduce nociception via modulation of arachidonic acid pathway. Indian J Pharmacol. 2013;45:479-82.

13. Elisabetsky E, Amador TA, Albuquerque RR, Nunes DS, Carvalho Ado C. Analgesic activity of psychotria colorata (Willd. ex R. and S.) Muell. Arg alkaloids J Ethnopharmacol. 1995;48:77-83.

14. Pal S, Sen T, Chaudhuri AK. Neuro psycho pharmacological profile of the methanolic fraction of Bryophyllum pinnatum leaf extract. J Pharm Pharmacol. 1999;51:313-8.

15. Ganguly S, Mula S, Chattopadhyay S, Chatterjee M. An ethanol extract of Piper betle Linn. Mediates its anti-inflammatory activity via down-regulation of nitric oxide. J Pharm Pharmacol. 2007;59:711-8.

16. Vaghasiya $Y$, Nair R, Chanda S. Investigation of some Piper species for anti-bacterial and antiinflammatory property. Int $\mathrm{J}$ Pharmacol. 2007;3:400-5.

17. Vinegar R, Schreiber W, Hugo R. Biphasic development of carrageenin edema in rats. $\mathrm{J}$ Pharmacol Exp Ther. 1969;166:96-103.

18. Maity TK, Mandal SC, Mukherjee PK. Studies on anti-inflammatory effect of Cassia tora leaf extract 
(Fam Leguminosae). Phytother Res 1998;12:221223.

19. Vane J, Botting R. Inflammation and the mechanism of action of anti-inflammatory drugs. FASEB J. 1987;1:89-96.

20. Gupta M, Mazumder UK, Kumar RS, Kumar TS. Studies on anti-inflammatory, analgesic and antipyretic properties of methanol extract of
Caesalpinia bonducella leaves in experimental animal models. Iran $\mathbf{J}$ Pharmacol Therapeut. 2003;2:30-4.

21. Hasan SMR, Jamila M, Muntazar MM. Analgesic and anti-inflammatory activity of the hydromethanolic extract of Mikania scandens wild leaves. Amer J Pharmacol and Toxicol. 2009;4:1-7.

Cite this article as: Reddy PS, Gupta RK, Reddy SM. Analgesic and anti-inflammatory activity of hydroalcoholic extract of Piper betle leaves in experimental animals. Int $\mathbf{J}$ Basic Clin Pharmacol 2016;5:979-85. 